\title{
Studying Elites in Early Islamic History: Concepts and Terminology
}

\begin{abstract}
This paper conceptualizes the term elite for the study of early Islamic history and aims to provide a usable definition for historians of early Islam. It gives an overview of existing terminology referring to socially dominant groups in Arabic and Persian sources as well as in the social sciences and related fields, discussing and dismissing its suitability for the field of Islamic Studies. The article traces the development of the term elite in scholarly discourse from the $19^{\text {th }}$ century onward and presents its own definition suited to the complex organizational structure of early Islamic society, pointing out both the challenges of and possible strategies for studying early Islamic elites.
\end{abstract}

Keywords: Elites; Islamic history; early Islamic Empire; Umayyads; 'Abbāsids; prosopography

\section{Introduction}

This paper is a collaborative effort by some of the team members working within the ERC project "The Early Islamic Empire at Work-The View from the Regions Toward the Center”, based at Hamburg University and led by Stefan Heidemann. The project seeks to study the early Islamic Empire from the inception of the Umayyad caliphate until the end of effective 'Abbāsid rule in the mid-10 ${ }^{\text {th }}$ century. It focuses not on the caliph (usually considered the lynchpin of the imperial enterprise) and his court, but rather on five key provinces (Ifrīqiya, al-Shām, alJazīra, Fārs, and Khurāsān) that serve as case studies illustrating the reciprocal relations and power dynamics between the so-called center and periphery.

One of the subjects investigated within the framework of this project pertains to early Islamic elites and their roles in connecting the empire across a vast territory inhabited by highly diverse subject populations. The elites we are primarily interested in are those who had a significant impact on the political dimension of the empire. They represent a key-albeit not the only-factor in understanding how the early Islamic Empire came into being and developed over time.

When we first began to study elites in our five provinces, we did not have a clear concept or definition of what we actually meant by the word elite. The individual members of our team held sometimes significantly divergent views of 
what elite status meant in an early Islamic context, and accordingly different ideas of what groups we should investigate. Moreover, our views were mostly informed by vague connotations of political power and wealth rather than a systematic approach to the issue. That this is true of the field of Islamic Studies more generally became obvious following our conference on regional and transregional elites in October 2016. Over the course of this conference, many fascinating and insightful papers were read and discussed. However, there were almost no references to theories or concepts of the study of elites in the 17 papers that were presented. The need for a more systematic approach to this subject was one of the main topics discussed during the concluding round table. This paper is a first step towards meeting this need. We seek to give an overview of how the study of elites has impacted our own research. We also offer suggestions on how to deal with this complex issue more generally, pointing out pertinent questions and difficulties as well as providing our own definition of socially dominant groups and individuals in the context of the early Islamic Empire.

As stated above, this project primarily considers the political dimension of the early Islamic Empire. We envision this dimension not as an abstract, rigid structure of institutions, but as a collection of relations between people forming overlapping networks. Three distinct but related levels are included: the judiciary, the military, and the administration. The administration represents the form in which the empire organized its claim to supremacy over its various subjects and territories. One key element of the administration was the taxation system, which represented "the principal point of contact between a state and its citizens"1 and was vital to the survival of the empire. The judiciary and the military both served to enforce the imperial authorities' claim to supremacy. However, these last two were not simply imposed by the imperial state on its subject population; they also reflected a demand for justice and security on the part of said subjects. This was particularly true of the judiciary, which was also less centrally organized than the military and not as well structured.

Apart from a comparatively small number of works on statecraft (e.g. 'mirrors for princes' literature, legal treatises), the bulk of our primary sources predominantly talk about people, not institutions or offices per se. This works to our advantage, as we are primarily interested in how the empire actually operated on the ground rather than how it was ideally supposed to work. We thus approach the early Islamic Empire from the perspective of those who held positions or offices within the framework of its institutions. In other words, we do not pursue an institutional approach focusing on the responsibilities and outputs of an of-

1 Grey 2011, 181. 
fice as an end in itself, but rather an actor-oriented one that studies the concrete actions of individuals holding a particular office. This better reflects the fluidity and diversity of a system whose rules could change depending on individual office holders and whose institutions often did not constitute diachronically stable and recognizable entities.

In this study, we look at two different (albeit sometimes overlapping) groups of actors who engaged with the empire's political dimension in all its forms. Primarily, we investigate those who held official positions within this dimension. However, we also study non-state actors, meaning individuals who were not appointed to a certain office or position by a member of the imperial apparatus but who nevertheless could and often did organize their communities. In her contribution to this volume, Petra Sijpesteijn highlights the role of non-state protagonists, both Muslim and non-Muslim, who were vital for the administration of justice on the local level in early Islamic Egypt. Such actors were instrumental in facilitating the smooth operation of the empire, but under certain circumstances they could also cause conflict. As engagement of any kind with the political dimension of the early Islamic Empire is the focus of our research, resistance to the enforcement of imperial dominion and/or imperial organization is also specifically included.

On a secondary level, we also investigate the economic dimension of the early Islamic Empire, i.e. the production of money and goods that kept the state running. Taxation was the empire's most important source of revenue. The comprehensive breakdown of the flow of taxation to the caliphal center in the so-called 'period of anarchy' contributed to the decline of 'Abbāsid power and the development of a polycentric Islamic Empire. That said, here we investigate economic structures and actors only as far as they are directly related to the political dimension. Both the political and the economic dimensions were present in varying degrees on every level of organization, from the village to the caliphal capital.

\section{Terminology}

One problematic aspect in the study of socially dominant groups is terminology. Any discussion of elites in the early Islamic period would be incomplete without considering what contemporary authors have had to say on the matter. Classicists often refer to elites by the terms used in their primary sources, but this is not as common a practice in the field of early Islamic history. Our primary sources also use many different terms to refer to various groups of higher status. Some 'political' texts develop a relatively complex classification of early Islamic 
society, ${ }^{2}$ but the most general and widespread concept comprises a bipolar description consisting of the undefined masses (al-'ämma) and the distinguished minorities (al-khāșșa). This distinction does not translate into a conceptualization of elites.

One of the main reasons why Arabic/Islamic terminology for elites is not often used by scholars in our field is that the terms' various connotations have overall not been studied in depth yet. The one exception is probably al-

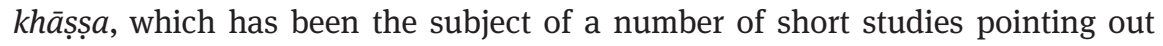
that the term is often mentioned in conjunction with al- 'amma, "the general people". Together, they constitute the entire population of a city or state. In this context, it can be translated as "the elite" or "the upper class". In other contexts, the term is variously used to indicate a ruler's entourage or, in a more restrictive sense, the caliphal family, "people of merit and quality" and "the rich and cultivated people". ${ }^{3}$

On the level below al-khāșșa, there are many terms describing leading groups in society at large or within specific communities. Some (at least initially) referred to specific criteria like honor (ashrāf) or ancestry (așilān, ahl al-manāqib, dhawì l-manāqib, buyūt(āt)), exemplariness (amāthil), or something that makes the group proud (mafākhir, mahāasin). Other terms are metaphors for being at the front or top of a group (wujūh, ru'as $\bar{a}^{\prime}$, a yān, șadr, taqaddum), for greatness (kibār, akābir, ajilla, buzurgān), or for manliness/vigorousness (fuhūul, sarāt). Some of these terms, like $a s h r a \bar{f}$, have found their way into scholarship as designations of particular groups, but only in specific contexts (such as the uprisings by Iraqi tribal leaders called al-ashrāf against the Umayyads), not as a general term for elites. ${ }^{4}$

While these terms appear to refer to certain (usually only loosely defined) social groups, none of them are suitable to describe the superordinate modern concepts of elites and their functions. For one, it seems difficult to relate any of these terms to various levels of social organization (from the village to the court, from military to religious groups). Some of them are too specific to one particular group and cannot be applied to members of other groups; others are too broad. Most of these terms are also value judgments (which we seek to avoid) and are too focused on one or two aspects of social dominance (e.g.

2 See e.g. Marlow 2016, I, 95-128 (ps.-Māwardī’s Nasīhat al-Mulūk).

$3 E I^{2}$, “Al-Khāșșa wa 'l-'Āmma” (M.A.J. Beg); Van Renterghem 2004, 183-5.

4 In South Asia, 'ashrāf' was (and continues to be) used to indicate the Arab origin of immigrants. See Dumont 1980, 207 ff. For discussions of $a s h r a ̈ f$ and other terms of social distinction in pre-modern Islamic history, see Van Renterghem 2004; Marlow 2016; Durand-Guédy 2010; and Yaacov Lev's contribution in this volume. 
wealth, political power, ancestry). This excludes important groups that do not fulfill the relevant criteria (e.g. merchants, scholars, elite women). Finally, these terms for elites also have different meanings in different chronological and geographical contexts, rendering them unhelpful for broader comparative studies and for research examining the general mechanisms and structures underlying the formation and development of socially dominant groups.

The term 'elite', which has been adopted in this paper, has become increasingly popular in Islamic Studies since the 1980s (see Fig. 1 below), following in the footsteps of academic disciplines such as history and the social sciences. It is certainly not the only term used to describe socially dominant groups: aristocracy, oligarchy, ruling class, notables, patricians, or upper class are just some of the most common alternatives. These are often used interchangeably with elite without proper distinction or clarification of their subject matter. ${ }^{5}$ Unfortunately, there is also no general consensus on what exactly these concepts denote and which phenomena they are meant to describe.

The term 'aristocracy' originally meant "rule of the excellent". It has since been used to describe vastly different social groups in vastly different contexts. It can be applied very generally to denote more or less closed-off ruling groups, ${ }^{6}$ whose composition is based primarily on ancestry but also on other criteria such as (landed) wealth and/or (hereditary) office. It implies recognition by other dominant groups as well as a particular lifestyle. ${ }^{7}$ While the term has a certain European ring to it, it can be used for some elite groups in early Islamic society, but it is not a viable alternative to the more general term elites.

The term 'patriciate' originated in a Roman context, but well into the $20^{\text {th }}$ century it was used to describe urban ruling elites in different contexts. Patricians were usually considered to constitute a social as well as a political group, defined by an association with wealth, prestige, ancestry, and social power. The distinction between the patriciate and the aristocracy is often unclear. ${ }^{8}$ The term was famously introduced into Islamic Studies by Richard Bulliet, whose pioneering 1972 work Patricians of Nishapur drew much praise but also criticism for its use of the term. The European connotations of the term have proven too strong for use in our field; Bulliet's use of the term has not taken hold.

'Oligarchy' or the "rule of the few" is another term that is frequently used to refer to dominant elites, focusing first and foremost on the ruling elite. The term

5 Morris 1990, 10. See also Gunn 2007, 195.

6 Dumolyn 2013, 5.

7 Wickham 2005, 154. For examples of other definitions, each with its own slightly different focus, see Fox 2014, 51, 52; Mitchell 1973, 27; Grey 2011, 122.

8 Dumolyn 2013, 4-5. 
does not primarily denote social distinction but belongs to the field of politics, and therefore cannot be used interchangeably with elite. ${ }^{9}$

The terms 'nobility' and 'notables' are still frequently encountered, but there seems to be a lot of conceptual overlap between nobility and aristocracy, especially regarding the weight given to ancestry. Notably, French scholars have argued in favor of using notables (Weber's "Honoratioren") to describe elites because the term is relatively open and can be applied to every level of society. The main criticism of this is that the term does not translate well, especially because in French academic discourse it is closely connected to specific historical contexts. $^{10}$

In the field of Islamic Studies, the notion of the "politics of notables" was first introduced by Albert Hourani in $1981 .{ }^{11}$ He applied this concept to the Ottoman period, and while Boaz Shoshan later argued for its usage in pre-Ottoman Islamic history, ${ }^{12}$ both understood notables to refer to urban dignitaries who engaged in 'politics' by “acting as intermediaries between the government and the people", ${ }^{13}$ usually without seeking autonomous rule for themselves. Both scholars were interested in the status of provincial towns vis-à-vis the imperial centers rather than the question of elite status and membership. Shoshan acknowledges the difficulties involved in dealing with notables as a "mixed bag of social groups" 14 but leaves open the question of whether "one [can] reach precision in treating the medieval Muslim 'notables"'. He simply defines the term as "standing for Arabic classificatory terms which suggest an elevated social position”. ${ }^{15}$

Concepts such as 'dominant' or 'ruling class' have mostly gone out of fashion as they are linked to Marxist theories that maintain the upper class should be comprised of those who hold the primary means of production. Since the second half of the $20^{\text {th }}$ century this has increasingly limited the appeal of these concepts to historians. Moreover, this particular definition does not apply fully to many socially dominant groups in history, such as the medieval patriciate. ${ }^{16}$

9 Beriou/Carraz 2015, 373.

10 Cébeillac-Gervasoni 2003, 704.

11 Hourani 1981.

12 Shoshan 1986.

13 Shoshan 1986, 181.

14 Shoshan 1986, 180. On the problem of defining 'notables' as a social group, see also Khoury 1983, 12-13, paraphrased in Shoshan 1986, 181.

15 Shoshan 1986, 181.

16 Dumolyn 2013, 5. 
Finally, German historiography puts forward the term Schicht ("stratum"), dividing society into an Oberschicht ("upper stratum") of patricians, a Mittelschicht ("middle stratum" of artisans and small merchants), and an Unterschicht ("lower stratum" of proletarians). It also identifies a Führungsschicht ("ruling stratum”), which can either be part of the Oberschicht or separate from it. This Führungsschicht has in turn been called a "political class" or a "power elite" by other sociologists. ${ }^{17}$

This short overview illustrates the great variety and occasional confusion regarding how a society's dominant social groups can be described. Here we use the term elite rather than the alternatives just described because it appears less influenced by specific historiographical approaches than other terms. Categories such as aristocracy or patriciate, for instance, have other connotations in academic and in public discourse that are often closely tied to specific historical contexts. Most of these connotations concern the right to rule, primarily in a political and military sense, and focus strongly on ancestry and wealth. Other (social, cultural, and religious) dimensions often fall by the wayside. Oligarchy is another good example of this: by focusing on the top level of a seemingly obvious ruling elite, it frequently fails to acknowledge the complex socio-political structures and hierarchies of medieval societies, with their often diffused systems of power. ${ }^{18}$ It also describes a type of government more than a group of people sharing certain defining characteristics. Finally, it is questionable to what extent ideas and concepts regarding other societies, such as medieval western European aristocracies, can be readily applied to pre-modern Islamic societies.

The term elite is not neutral either, and it does contain problematic aspects inherent to both the concept itself and to how the concept has been employed in elite studies. ${ }^{19}$ Normativity, for instance, is one such problem. In common usage, the term elite has a number of connotations, mostly associated with notions of excellence, upper-class status, privilege, and superiority. As current public discourse in the political sphere illustrates quite nicely, however, identifying something as elite can also take on negative associations very quickly. We thus want to emphasize here that we do not use the term normatively, but only to describe certain mechanisms and functions underlying social structures. As postulated by Vilfredo Pareto, one of the founding fathers of elite theory, in our work the term

17 Dumolyn 2013, 6-7.

18 Dumolyn 2013, 6. See also Haldon 2004, 6.

19 See e. g. the "areas of concern" identified by Gunn 2007, 195-198, and his suggestions for how to deal with these concerns, ibid., 198-202. 
elite will be "treated as a value-free term meaning those who score highest on scales measuring any social value or commodity". ${ }^{20}$

Systematic definitions of elite are few and far between not only in our field, but also in many works of historical sociology and the various branches of history. ${ }^{21}$ In part, this is due to a lack of precision regarding the term and the analytical category of elite. ${ }^{22}$ This is aptly summarized in a well-known quote by the political scientist George Marcus:

Clear in what it signifies but ambiguous as to its precise referents, the concept of elite in general usage has a certain force; it locates agency in social events, by evoking the image of a ruling, controlling few, while being intractably vague. ${ }^{23}$

However, the vagueness of the term can also be viewed as an advantage:

Indeed, the notion of "elite" is often deliberately used because it is a vague one. Usually it does not become really clear what the term exactly denotes and this gives the historian the liberty to define it exactly as she or he wants to or, as is regrettably often the case, not to define it at all. ${ }^{24}$

Another advantage of employing the term elite to delineate socially dominant groups is that it can be used across all levels of the social hierarchy, ${ }^{25}$ highlighting similarities between structures and processes that otherwise seem very different.

Finally, it appears that elite has superseded, although not entirely replaced, the other terms discussed above in the academic discourse of the last 30 years. ${ }^{26}$

\section{The Theoretical Study of Elites}

Having decided to use the term elite, our first step towards a conceptualization of early Islamic elites was a foray into the social sciences. The study of elites has been a well-established field within the disciplines of sociology, political science, psychology, and related subjects for about a century. Much of what has

20 Zetterberg 1968, 8.

21 Dreyer/Mittag 2011, 9-10.

22 Gunn 2007, 191.

23 Marcus 1983, 7.

24 Dumolyn 2013, 3. See also Settipani 2006, 14.

25 Wickham 2004, 285; Couperus et al. 2004, x-xi.

26 Dumolyn 2013, 4; Gunn 2007, 198. 
been done in that regard is not particularly useful for or applicable to early Islamic history, as many theories were advanced on the basis of research into the emerging elites of $18^{\text {th }}$ - to early $20^{\text {th }}$-century European history. In fact, the term elite appeared in Western social and political thought only in the late $19^{\text {th }}$ century: "the notion of elite is an academic and post-hoc construction. There is little evidence that historically people have thought of themselves as members of an elite per se."27 We cannot therefore simply impose definitions of elites derived from the social sciences onto our own field of history.

Since antiquity, there have been discussions of social and moral distinction, and the concept of elite (if not the term itself) is sometimes traced as far back as Plato. ${ }^{28}$ Its systematic development into a number of theoretical frameworks is based in modern sociology, namely the works of Vilfredo Pareto, Gaetano Mosca, Max Weber, and C. Wright Mills (to mention some of the most prominent early theoreticians). The conceptualization of modern sociological elite theory developed in the $19^{\text {th }}$ century in the aftermath of the social upheaval caused by the French Revolution, in dialogue with and as a counterparadigm to Marxism. ${ }^{29}$

At the core of the sociological elite theories developed by $19^{\text {th }}$-century scholars lies the assumption that elite rule is inevitable. Rather than economics and class-like collectivities, it is elite choices and power competitions, and thus to a certain degree the wider social order, that determine politics: "in the elite paradigm... tiny but powerful minorities are made up of autonomous social and political actors who are interested in maintaining and enhancing their power." 30

Since the early $20^{\text {th }}$ century, an increasing number of sociologists have contributed to the conceptualization of elites. Vilfredo Pareto distinguishes between governing and non-governing elites. He further separates governing elites into those who dominate by force and those who dominate by skills and persuasion. In a number of works, the first of which was published in $1901,{ }^{31}$ Pareto puts regime change down to the "circulation of elites" as new elites constantly arise to take the old elite's place. ${ }^{32}$ His elite theory does not provide criteria of measuring

27 Gunn 2007, 196.

28 Dartmann et al. 2015, 37; Daloz 2010, 7-13.

29 Dartmann et al. 2015, 37; Gunn 2007, 191-192.

30 Higley/Pakulski 2012, 321.

31 Pareto 1968.

32 For Pareto, regime change does not occur because rulers are overthrown from below, but because one ruling elite replaces another. The functioning of elite and society depends on a constant circulation of elites. Elite groups decline, degenerate, and die, decaying in numbers as well as quality. This creates room for the entry of new elements from other parts of society, and the 
and distinguishing the superior qualities of its subjects, and it should be noted that Pareto, though often reduced to his interest in elites, was mainly concerned with social behavior. ${ }^{33}$

In his 1939 book Ruling Class, Gaetano Mosca stresses the material conditions as well as the intellectual and moral superiority of the ruling elite. ${ }^{34} \mathrm{He}$ also points out the organizational skills that enabled elites to gain political power. For Mosca, elite status is not hereditary in nature, but attainable by all classes. Legitimizing the power of (governing) elites and constructing ideological foundations to defend their rule thus forms an important part of Mosca's work. ${ }^{35}$

Max Weber does not use the term elite himself. He does refer to "leaders" (Herren, Herrscher), their (administrative) "staff” ([Verwaltungs-]Stab), and "ruling minorities" as the apex of a bureaucratized state apparatus. Like many elite theorists, Weber is concerned with effective governance. Through his focus on power concentration and legitimacy of rule (closely related to mass consent) he stresses the advantage of small numbers as an attribute of dominant groups. A ruling minority, according to Weber, can communicate rapidly to organize its own defense. Furthermore, it has the advantage of being able to keep its knowledge, intentions, and decisions secret. ${ }^{36}$ Authorized elites gain autonomy, which is necessary for rational, consistent, and responsible ruling. Weber's analyses of the structure, integration, and dynamics of these ruling minorities and their monopoly on legitimate power have greatly influenced elite research and theory. Additionally, his concepts of power and domination (through control exerted mainly in the economic sphere and/or by virtue of authority) have become a fundamental pillar of current elite theories. They anticipate the work of those contemporary elite theorists who focus on elite structures, modern nation-state based elites, elite integration, and ruling consensus. ${ }^{37}$

After the Second World War, the concept of elites was developed further by C. Wright Mills and other American scholars, who used the concept to criticize the state of American democracy. In his book The Power Elite (1956), Mills demonstrates the entanglement of interests of different elite groups in American so-

\footnotetext{
"circulation of elites" is set in motion. Only constant exchange and circulation between the governing elite and the governed society can ensure the rise of new elites capable of governing according to the developing needs of that society and thus providing social stability. For a detailed overview, see Kolegar 1967.

33 López 2013, 2; Van Renterghem 2004, 75.

34 Mosca 1939.

35 Endruweit 1979, 38-39, 41-42.

36 Weber 1922, 603-612.

37 Pakulski 2012, 39-44.
} 
ciety. He describes the resulting power elite as consisting of "those political, economic, and military circles which as an intricate set of overlapping cliques share decisions having at least national consequences." ${ }^{38}$ He does not regard the power elite as one homogenous group, as factions and conflicts of interests do exist. Nevertheless, the internal discipline and community of interest of the power elite is more powerful than the divisions among them. ${ }^{39}$ Whether or not the members of the power elite make decisions is less important than their potential to do so, due to their command of the major hierarchies and organizations of society. ${ }^{40}$

Since the mid-20 ${ }^{\text {th }}$ century, the literature on elites has grown exponentially in the social sciences and in adjacent fields like history. The 1970s and 1980s saw a debate in social history regarding whether class or elite was a more useful concept, with the former often predominant. Historians came to different conclusions regarding the nature of the political ruling class compared to the relative power of wealthy groups like landowners or industrial magnates. These differences often turned on possession of wealth versus possession of office. However, the period in question "also saw an increasingly self-conscious effort in urban social history to bring the elite model and the class model into a more fruitful rapprochement."41

The conceptualizations and definitions of elite groups developed over the past century vary greatly. Almost all theorists agree that the elite is a minority consisting of those members of a social system who due to selective criteria consider themselves superior to others and/or are considered superior by others. ${ }^{42}$ Determining the nature of the selective criteria used heavily depends on the researcher's focus and approach. Function, moral qualities, or merits and achievements are just some of the possible elite characteristics considered. ${ }^{43}$ Pareto's and Mosca's theories, for instance, can both be classified as a positional approach, as they are mainly focused on status-based elites, i.e. elite status as determined by one's position within the socio-economic structures of a given society. As the title of his main work implies, C. Wright Mill's concept of elite follows a power approach. Weber's theory of socially dominant groups can be described

38 Mills 2000, 18. See also Horowitz 1981, 376.

39 Mills 2000, 283.

40 Mills 2000, 286.

41 Gunn 2007, 193.

42 Endruweit 1979, 34.

43 See e.g. Endruweit 1979, 36-37. 
as a functional approach, where elites are defined by their ability to preserve, shape, and/or re-shape a social context. ${ }^{44}$

\section{Studying Elites in an Early Islamic Context}

An analysis of the use of the term elite in book and paper titles in the Index Islamicus, our field's most important bibliographical database, shows that the term elite came into vogue in the 1960s. However, it only took root in studies on pre-16 $6^{\text {th }}$-century Islamic history in the late 1990s (see Fig. 1). Of course this does not mean that elites were not the focus of research prior to the 1990s. Other terms were used instead to convey similar concepts, but since the 1990s elite has become the main paradigm employed. ${ }^{45}$

When previous research on early Islamic elites is more closely examined, the first observation is that even in cases where the term elite is used, a theoretical framework for it is often missing. This is no surprise: in comparison with Roman, Greek, or medieval European history, Islamic history generally has only recently begun to apply a theoretical framework to its work. This is partly due to the fact that our discipline is very young compared to those fields and still lacks much basic groundwork. Many sources (manuscripts, inscriptions, papyri) remain unedited or even unknown, most subjects have been studied only superficially, ${ }^{46}$ and research tools indispensable in other fields are lacking in ours. ${ }^{47} \mathrm{~A}$ second, related problem is that the relevant theoretical frameworks and methodologies have been developed within European milieus and are often not easily translated to other contexts. Moreover, much of early elite research in our field was based on the study of biographical dictionaries, producing work over-focused on religious scholars. ${ }^{48}$

44 Endruweit 1979, 38-39, $43-44$.

45 For example, in his famous pioneering study on the urban elite of Nishapur Richard Bulliet decided against the use of the term elite. In his view the term does not "convey the important concept of heredity that characterized the group" (Bulliet 1972, 20). He opted instead for "patricians'.

46 For example, Almut Höfert states that the catalogue of the library of the University of Basel contains about 52 biographies of Charlemagne, while for the fifth Umayyad caliph 'Abd al-Malik b. Marwān only one biography exists (Höfert 2015, 60).

47 For the study of elites, for instance, we lack onomastica and (diachronic and synchronic) lists of functionaries, the basic tools of the study of elites in the Roman world.

48 In Roy Mottahedeh's words: "Ulamalogy is a noble science-at least we have to think so, because it is almost all the Islamic social history we will ever have.” (Mottahedeh 1975, 495.) 


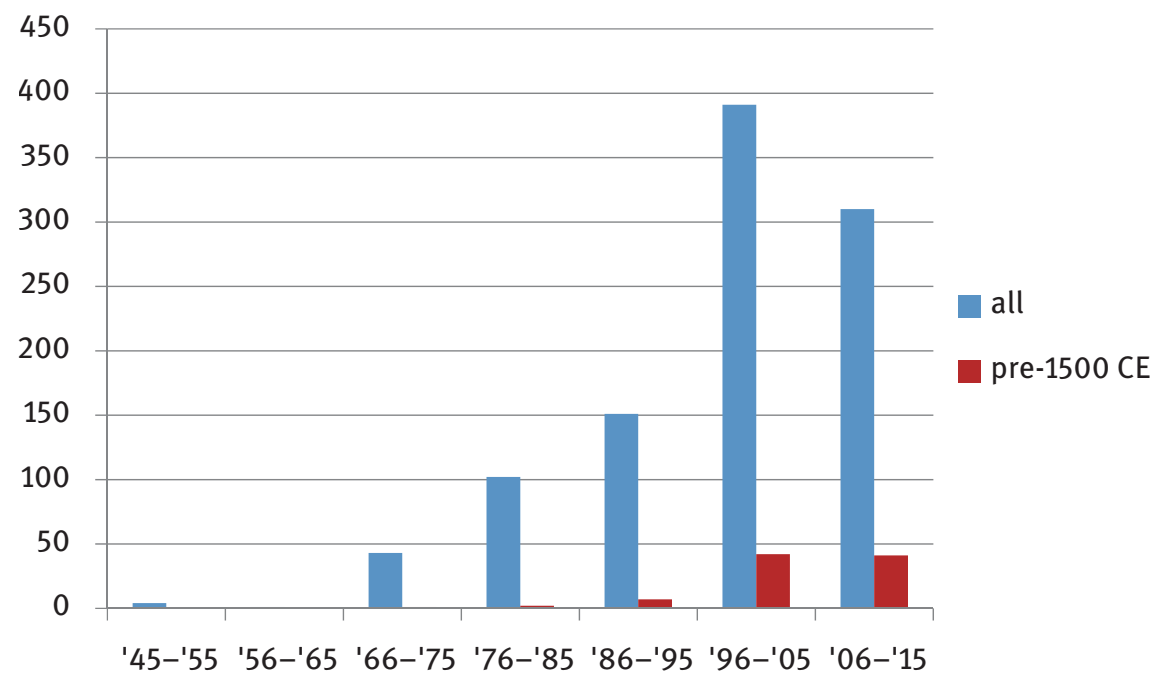

Fig. 1: Analysis of titles of articles and books from 1945-2015 listed in the Index Islamicus that have "elite" in the title. The red columns mark the titles of studies that focus on pre- $16^{\text {th }}$-century history.

The 1999 workshop on elites in the Byzantine and early Islamic Near East at the University of Birmingham marks an important turning point in the history of the study of early Islamic elites. The proceedings, which were edited by John Haldon and Lawrence Conrad and published in 2004, ${ }^{49}$ contain a good overview of the state of the subject at that point in time and a number of important case studies. Both Haldon's introduction and Chris Wickham's conclusion provide a valuable first attempt to place the study of elites in early Islamic history within a theoretical framework.

Since then, a substantial amount of research has been conducted on early Islamic elites of different types. Military, political, judiciary, religious, intellectual, ${ }^{50}$ Jewish and Christian, ${ }^{51}$ court, urban, and local elites ${ }^{52}$ have been the subject of case studies in the last 20 years. Their backgrounds, relations, roles in society,

49 Haldon/Conrad 2004.

50 E. g. Kennedy 1981; Toru/Philips 2000; Van Steenbergen 2005; Hirschler 2008; Lev 2007; Ahmed 2011; El Hour 2012; Nef 2004; Christys 2018.

51 E. g. Payne 2015, 5-32.

52 E. g. Fuess/Hartung 2011; Durand-Guédy 2010; Preiser-Kapeller 2018. 
lifestyles, sources of income, ${ }^{53}$ and intra-elite social processes have all been studied.

Unfortunately, most of these studies are thin on theory and conceptualization. It remains to be seen whether the few meaningful exceptions will significantly impact future scholarship in our field. ${ }^{54}$ Concepts like 'the 'ulama $\bar{a}$ ', 'the army', or 'the political ruling class' are often used as though they are self-explanatory and as though they self-evidently represent the only or primary elite of early Islam. All too often the term elite is used in the singular, implying the existence of a single, somehow unified upper class.

\section{Definitions}

As discussed in the preceding section, one of the reasons we chose the term elites is that it is relatively neutral compared to other designations. We must now clearly outline our understanding of what it covers and the contexts in which it is applied.

We define elites in the context of the early Islamic Empire as individuals and groups of individuals who were in a position or had the potential to influence social, political, economic, and religious processes and decision-making in their communities. These communities existed on every level of organization, from the village to the court, the Church to the army, and merchants to qā dìs. They gained influence through a combination of some or all of the following resources:

- Ancestry (including [constructions of] ethnic, tribal, and family affiliation)

- Exceptional personal qualities (such as charisma, intelligence, strength, or poetical/musical talent)

- Wealth (from inheritance, landownership, commerce, gifts, salaries, corruption, etc.)

- Military power

- Education/training

- Office-holding

- Personal relations (retainers, clients, supporters, patronage, marriage patterns)

53 E.g. Kennedy 2011, 54-79.

54 E.g. Van Renterghem 2004; Paul 1996; Paul 2016. 
We consider the first two criteria 'internal factors', not bestowed by outside forces but inherent to an individual. The remaining resources we consider 'external', in the sense that an individual would need the support or patronage of others to achieve access to them.

The boundaries between these categories are not absolute, of course. The integration of an individual or a group into a more prestigious tribal faction, for example, could improve access to other resources. Poetical talent needed to be discovered, fostered, and honed, which almost always required the input of teachers. Conversely, one could argue that being born into a wealthy family or a family of scholars provided an individual with automatic access to these resources. Nevertheless, we believe the difference between these two kinds of resources significant enough to justify a formal distinction.

The above resources correspond roughly to what Mann calls the "sources of social power" 55 and Bourdieu "types of capital" in his "field theory" 56 of interaction between social actors. Resources are almost always interdependent, and access to one usually facilitates access to others. Attaining them provides an individual with access to networks and bestows status and privileges, consolidating and advancing (potential) ability to influence processes and decision-making.

Status is a multifaceted concept, and it is often futile to attempt to boil down each individual's claim to elite status to one main factor. In one sense, it corresponds to Bourdieu's notion of "symbolic capital", which is determined by how other social actors perceive different types of capital (economic, political, etc.) in an individual or a group. In our conceptualization of elites, such capital, whether ideological or symbolic, is thus considered to derive from the basic resources just mentioned. It is not a resource in and of itself. This is closely related to the issue of representation. Elites do not legitimize themselves. They claim legitimacy on the basis of a number of criteria such as descent or wealth. Bourdieu stresses that elites use "taste" (in music, literature, food, clothing, etc.) and lifestyle as a way to distinguish themselves from non-elites. The acceptance of the superiority of these preferences by subordinate groups he considers a form of symbolic violence. ${ }^{57}$ This brings up an important point: whether or not elite status is bestowed depends on its acceptance by the target audience. Status is thus always a process of (asymmetric) negotiation: "elites should be viewed not only as the product of struggles between elites (Pareto's 'circulation'), but also a product of

55 Mann 1986.

56 Bourdieu 1979, 1986.

57 Bourdieu 1979. 
struggles about the definition of eliteness, about what came to count as 'elite' at any given historical juncture." 58

We specifically stress both the vertical and the horizontal heterogeneity of elites. Village elites often had very little standing in the next big city; urban notables did not necessarily enjoy elite status at the caliphal court. Dorotheos of Gaza, a $6^{\text {th }}$-century Christian monk, once remarked that a man who was a leader in Gaza would be a lesser figure in Caesarea, a peasant in Antioch, and in Constantinople a poor man. ${ }^{59}$ Elites are thus not internally egalitarian, but can be highly stratified. ${ }^{60}$

On the other hand, several different elite groups could exist at the same level of organization. ${ }^{61} \mathrm{~A}$ city or province, for example, will have many more or less distinct groups claiming elite status, such as religious authorities (of all denominations), office holders (e.g. leaders of the army or armed forces; qāạīs), and economically dominant actors (e.g. landowners; rich merchants). There could be and often was some overlap between the different elite groups. ${ }^{62}$ Moreover, individuals could be part of more than one elite group or move from one elite segment to another. One example is Muhammad al-Shaybānī, the famous 'Hanafî' jurist: he was born into a prosperous family as the son of a military officer, but chose a religious career in the course of which he rose to the top of the intellectual elite thanks to his erudition. This granted him access to official state positions, and he was appointed as qā direct access to Hārūn al-Rashīd. ${ }^{63}$

It is thus important to recognize that "elites themselves were mobile and permeable, not the separate monoliths of sociological imagination." ${ }^{44}$ As indicated in the introduction to this paper, we should view a pre-modern society in particular as:

...a fluid social space rather than as [a] fixed structure or hierarchy, in which individuals and groups were in constant movement relative to others...[remembering] the porousness

58 Gunn 2007, 200 - 201. See also Tacoma 2006, 159.

59 Quoted in Wickham 2004, 285. See also Fox 2014, 52.

60 Tacoma 2006, 13.

61 See also Gunn 2007, 199.

62 Couperus et al. 2007, xi.

63 See also the example of Augustine of Hippo as described in Wickham 2004, 285, and the collection of studies on local elites under Hellenistic kings in Dreyer/Mittag 2011, 290.

64 Gunn 2007, 199. 
of the boundaries that divided elites from one another and the often fragmentary nature of their networks. ${ }^{65}$

We believe that a relatively wide definition of elite is necessary to indicate that while the local contexts of different elites, and thus of their formation, development, and functions, might vary, the underlying structures and patterns that govern elites are very similar. Finally, when talking about elite actors in the early Islamic Empire, we will use the term in its plural form to emphasize the diversity and complexity of early Islamic social structures and to acknowledge that the term refers to very different social and historical contexts. ${ }^{66}$

\section{Operationalizing the Term Elite for Early Islamic History}

The study of elites is of course based on the investigation of people. However, the question of which people fall under this definition is far from straightforward. The major issue of research on elites, and historical elites in particular, is selection. Which groups and actors are considered elites and selected for study? How are defining characteristics such as power and influence displayed in the sources? Is an empirical study of these characteristics possible at all? What we need to keep in mind is that definitions and categories "are not intrinsic to narrative" but imposed by the researcher. ${ }^{67}$ The selection and definition of elites thus says as much about the scholar as it does about their subjects of study and sources. Scholars need to be aware of how their own beliefs and theories shape these very subjects of study:

In most cases, however, the target group is not a group in the sociological sense... The group is created and analysed by the researcher himself, e. g. the power elite, the marginals, the migrants etc. This is no problem as such but one has to avoid turning the target group into a social group in itself with a distinctive characteristic and 'group solidarity'. ${ }^{68}$

Closely connected to the question of which groups and individuals should be considered elites is the complex issue of how far to extend the boundaries of

65 Gunn 2007, 199. Gunn is referring to urban Victorian societies, but his remarks certainly apply to (pre-modern) societies in general. See also Tacoma 2006, 158-160 (on the concept of "cyclical mobility"), 271.

66 Dumolyn 2013, 8; Bériou/Carraz 2015, 373.

67 Robinson 2003, 57.

68 Verboven et al. 2007, 51. 
an elite group. If we study office holding as a criterion of elite membership, for example, should we investigate all office holders from the qāọi $l$-quḍāt to local prison administrators? What about prominent families; did all 'Alids by virtue of their claim to Prophetic descent possess elite status, regardless of their actual status and real living conditions? Can we consider all Arab tribesmen of the conquest period to constitute one elite? How do we approach mawāli whose patrons fulfilled the criteria just specified: does or should elite status extend to them?

Most often, context is the deciding factor in answering these questions. Within the framework of our project, we are primarily interested in those who were based in our five key provinces and in a position to at least potentially influence the political dimension of the empire. This influence could exist because they held offices in the state apparatus or because the influence they exerted over their communities had an effect on the functioning of the empire at the local, regional, and/or imperial level. Rebels and non-Muslims are explicitly included as potential elites. We investigate questions of loyalty and are especially interested in the reciprocal dynamics between the empire and its elites: to what extent did the imperial level rely on regional elites? How important was imperial support for local and regional elites? What role did factors like kinship play in gaining and maintaining elite status?

There are other difficulties involved in studying pre-modern Islamic elites. As all historians of early Islam are very much aware, the sources at our disposal can make the study of people and events somewhat difficult. Except for the highest positions in provincial administration, they provide information for only a fraction of the people and groups we are interested in regarding our provinces. Even on the highest level, that of the governor, surviving information is by no means complete. ${ }^{69}$ Moreover, certain groups, especially non-Muslims, hardly appear in the Muslim sources.

The project takes a prosopographical approach, which is well adapted to dealing with scarce data: we focus on individuals, but also try to discern patterns that give insight into phenomena that transcend individual lives. This is not to say that all tax collectors, landowners, or army commanders will be treated as coherent groups. Moreover, there is of course concern about generalizing patterns from very incomplete information on far-from-complete samples: research on the $q \bar{a}$ dịs of three cities in the Jazìra, for instance, has revealed that the identified office holders sometimes differed significantly in terms of background, education, access to professional and official networks, and/or standing in their

69 See e.g. the study of governors of al-Shām and Fārs by Simon Gundelfinger and Peter Verkinderen in this volume. 
communities, to name just a few aspects. ${ }^{70}$ Similar concerns apply to so-called social categories like slaves or mawāli. ${ }^{71}$ However, we do think it is possible to detect patterns that transcend the individual level, and this is borne out by the evidence. Clear patterns can be discerned between the Jaziran cities regarding the backgrounds of appointees, although they are at least in this case tied to specific locations. Furthermore, while the Jazīran $q \bar{a}$ ḍis mentioned earlier all differed in their level of education and social mobility, almost all of them trained as hadith scholars before taking office.

Our investigations of the relevant individuals and groups also vary from province to province. Ifrīqiya, with its Berber population, Ibāḍi rulers, and heavy involvement in the slave trade, requires a different approach than, for instance, the Jazira or al-Shām, with their prominent Christian elites and more noticeable state presence. Needless to say, each key province also has its own source base, which we attempt to widen as much as possible. For example, Ahmad Khan studied elites in the province of Khurāsān. His work is partially based on a small but crucial corpus of documentary sources from $8^{\text {th }}$-century Khurāsān. These documents pertain to a limited range of regions within the province of Khurāsān, but they nevertheless provide fascinating and (most importantly) direct and reliable insight into the workings of the early Islamic Empire and the mobility of elites in a remote region. ${ }^{72}$

Other regions boast a different set of sources. Christian works are a major asset for the study of the early Islamic Jazīra and al-Shām. They offer a look at administrative and legal structures that were parallel to and sometimes intersected with the caliphal state. ${ }^{73}$ Just as significantly, Christian chronicles can also serve as repositories of otherwise forgotten details of early Islamic history. The local Arab lords that effectively controlled a considerable area of the Jazira in the $9^{\text {th }}$ century appear on a few coins from Northern Mesopotamia, but we have to turn to Bar Hebraeus (d. 1286) and Elias of Nisibis (d. 1046) for information on their identity, actions, motivations, and ultimate fate. In Fārs, local lords and Kurdish chieftains played an important role, but they are rarely mentioned in the Islamic sources. We make an extra effort to thoroughly study the few that are attested, following the example of Jürgen Paul's investigation of Muhammad b. Wāșil in his contribution to this volume. Ultimately, we seek not only to ex-

70 See Hannah-Lena Hagemann's contribution to this volume.

71 The meaning of the term mawāli is controversial, in both primary sources and scholarship. For an introductory discussion, see $E I^{3}$, "Client" (J. Nawas) and the references listed there.

72 See Ahmad Khan's contribution to this volume.

73 See Philip Wood's contribution to this volume. 
pand the usual source base, but also to push the standard Muslim sources and tease out information on underrepresented and understudied groups.

\section{Studying Early Islamic Elites}

There are many different ways of studying early Islamic elites. Due primarily to the nature of our sources, the methods most commonly used are prosopography and biography. Recent examples of the application of these methods can be found in Asad Ahmed's or Teresa Bernheimer's research on genealogy and marriage patterns and Van Renterghem's study of Baghdādī elites in the Seljuk period. Within our own project, we are in the process of building up a database of early Islamic personnel that will be made available to the public once the project finishes. ${ }^{74}$ Unfortunately, a complete ethnography of the empire or a full prosopography is not possible, as such a task requires more evenly-distributed biographical data than historians of early Islamic history have at their disposal.

Network analysis is another promising approach slowly being added to the methodological toolkit of early Islamic history. It has yielded fascinating results in neighboring disciplines such as Byzantine Studies and medieval European history; Johannes Preiser-Kapeller has published most extensively on the use of network analysis in Roman and Byzantine history. ${ }^{75}$

Finally, the Digital Humanities have already provided many useful tools that can be adapted to the study of early Islamic elites. ${ }^{76}$ The groundbreaking work of Maxim Romanov and the KITAB project led by Sarah Bowen-Savant have the potential to give fresh impetus to researchers seeking new ways of understanding the history of the early Islamic world. ${ }^{77}$

To use our own work as an example, the most important issues concern the selection of individuals to be studied and the kind of information we seek. Individuals and groups are chosen in a variety of ways. We look for all the incum-

74 Beginning in the 1990s, similar databases were set up by a few other scholars, most notably by Michael Lecker for his ongoing Jerusalem Prosopography Project (JPP), and by John Nawas and Monique Bernards within the framework of the Netherlands Ulama Project (NUP; 19942000). The former database is partially accessible to the public, but to our knowledge the latter cannot be accessed. For more information on JPP, go to http://micro5.mscc.huji.ac.il:81/JPP/ homepage/ (last accessed 31 July 2018). On the Netherlands Ulama Project, see Nawas 1998. 75 See Preiser-Kapeller 2012 and 2015.

76 For an example of the use of digital tools within our own project, see Haro Peralta/Verkinderen 2016.

77 See Romanov 2013; http://maximromanov.github.io; http://kitab-project.org (last accessed 31 July 2018). 
bents of certain offices discoverable in written and material sources (such as coin collections). Using Jedli, the digital tool we developed for this project, we also search for names and offices connected to certain places in our provinces. ${ }^{78}$

On the basis of the lists thus compiled, we look for all the relevant contacts of our chosen individuals to further expand our collection of early Islamic elites. The primary features we investigate are family background, including the social and professional careers of family members; social, geographical, and professional mobility including marriage patterns; education; networks of patronage, commerce, religion, and so forth; and office holding and the tasks associated with exercising said office(s). We are less interested in representations of elite status in written and material culture. The question of representation is of course not a purely literary issue independent from social practice, but as it is one of the few reasonably well studied aspects of early Islamic elites we instead focus on the features listed above. ${ }^{79}$

One subject we are particularly interested in is that of changing elites. The classic example is the military elite on the imperial level. Initially the military consisted mostly of Arab tribesmen, who in the wake of the 'Abbāsid revolution were largely replaced by Khurāsānians, who were in turn superseded by Central Asian ('Turkish') elites. We seek to detect similar structural changes on the provincial or local level of the empire that might or might not mirror developments on the imperial plane. These can differ from region to region. In order to study elite groups on these different levels, we use a rough classification of local, regional, and transregional elites.

Under local elites, we subsume all those whose power, influence, and contacts were mostly concentrated on the level of their own city or rural area. We are forced to focus mostly on urban elites in the provincial cities, since with few exceptions data on rural contexts is unfortunately scant for our regions. As outlined in Hannah-Lena Hagemann's contribution, a good example of this type of elite are the qā and were deeply involved in the network of hadith transmitters in their city. The ancestors and descendants of many of them can be shown to have been active in Harrān, but most of these qā dị̂s are not attested to very far outside the city as holding offices or pursuing education or trade. A clear-cut distinction between the urban and the rural contexts does not exist, of course. Landlords often lived in the city, but their influence certainly extended at least to their city's hin-

78 On Jedli, see Haro Peralta/Verkinderen 2016. To download Jedli, go to our website at https:// www.islamic-empire.uni-hamburg.de/en/publications-tools/digital-tools/jedli.html.

79 See Genequand 2006; Fuess/Hartung 2011. 
terland. Nevertheless, our information on the rural population is very limited. There are other difficult questions: how long did one have to have lived in one place to count as local? How did the imperial administration, for example, identify local elites? ${ }^{80}$ These and other issues mostly have to be investigated on a case-by-case basis.

We call regional elites those whose influence was not limited to one specific urban or rural area, but whose remit still did not spread far beyond the horizon of the province (in our understanding, the province is the organizational form of the region). This type of elite is exemplified by the figure of Muhammad b. Wāșil. He belonged to a family of Arab immigrants in Fārs who had been settled there for many generations. There they built up a regional power base, eventually controlling about one third of the regional kharāj. Muhammad b. Wāșil stepped in to fill a power vacuum in Fārs in the Samarran period, but never attempted to spread his influence to other regions. ${ }^{81}$ It is often difficult to distinguish clearly between local and regional elites, and indeed significant overlap between the two was the norm. ${ }^{82}$

Elites active in more than one province are called transregional elites. This transregionality can be expressed in three major ways: transregional mobility (e.g. Ibādī traders with bases in Bașra and Ifrīqiya $\left.{ }^{83}\right)$; transregional influence (e.g. Muslim scholars with influence in different regions, though this did not necessarily mean they were very mobile themselves-see figures such as Ahmad b. Hanbal); and transregional power (e.g. super-governors who headed more than one province at the same time).

These terms-like the realities they describe-are very fluid and can be used for both elite groups and individuals. It was possible to move between these different elite levels. For instance, the Aghlabids started out as a transregional elite, but once entrenched in Ifrīqiya they became a regional one.

\section{Conclusion}

The paper at hand has suggested how early Islamic elites can be studied and provided an overview of the difficulties involved in this pursuit. It aimed to illustrate some of the important questions that need to be asked and the ways in

80 On problems concerning the study of local elites, see Dreyer/Mittag 2011, 7-10.

81 See Jürgen Paul's contribution to this volume.

82 For an example of the intertwined nature of local and regional elites in late antique Egypt, see Tacoma 2006, 115-116, 141, 149.

83 See Cyrille Aillet's contribution to this volume. 
which our sources can best be exploited in order to investigate socially dominant groups within the early Islamic Empire. It also sought to draw attention to the crucial need for terminology and definitions. We opted for the term elite, but what matters is not so much what term is used but that its meaning within a particular research context is clearly defined. This is particularly important because of the diversity of elite groups over both time and space, along a vertical and horizontal continuum of social hierarchy.

Much of this paper has turned on questions of terminology, definitions, theories, and concepts. These are rather dry subjects, and not least because of that many historians are reluctant to make use of theories developed in other disciplines. Indeed, why use theory at all in historical research?

First and foremost, theory provides historians with a common language and vocabulary. The point here is not for all historians to arrive at an absolute theoretical consensus-that will remain impossible. But historical sociology, for example, offers models that might allow researchers to understand each other better and facilitate larger comparative studies. It is not even necessary to agree on the use of specific terms: one scholar's patricians might be another's notables and yet another's urban elite. However, an exchange on the subject of theory can help specify and stabilize the contents of the terms we all use. This is particularly true in our field of early Islamic history, which is nowhere near establishing a more or less coherent vocabulary of empire and elites. Comparability is another factor. Often, historians insist on the uniqueness of the historical contexts they investigate. While that is certainly true to an extent, some of this emphasis on uniqueness is due to the fact that researchers are put off comparative work in part by seemingly different terminology that in reality often describes similar structures and processes.

Another reason why it makes good sense to engage with theory-and not just when discussing elites-became obvious in the process of writing this paper. As Mann puts it, "a strong sense of theory enables us to decide what might be the key facts, what might be central and what marginal to an understanding of how a particular society works." ${ }^{84}$ Just as importantly, we have to systematically confront our own preconceptions regarding the nature of the early Islamic Empire and its elites: "If historians eschew theory of how societies operate, they imprison themselves in the commonsense notions of their own society." 85

Finally, developing theoretical approaches within (early) Islamic Studies does not only improve our understanding of (early) Islamic history, but also fos-

84 Mann 1986, vii.

85 Mann 1986, vii. 
ters a dialogue between our field and other disciplines such as Roman and Byzantine Studies, Chinese and Indian Studies, ethnology, historical sociology, and anthropology. Instead of isolating itself (from the field of history in particular) with assertions of uniqueness, ${ }^{86}$ Islamic history can thus fully participate in the fruitful exchange of interdisciplinary research.

Nevertheless, despite the importance of a theoretical framework, it is of course equally necessary for historians to build theories from the ground up, basing ideas off their source material rather than simply imposing a model upon their work. The great sociologist Michael Mann argues that this "zigzagging” between data and theory is the only way to achieve a working and workable model of any historical society:

The real world (historical or contemporary) is messy and imperfectly documented; yet theory claims pattern and perfection. The match can never be exact. Too much scholarly attention to the facts makes one blind; too much listening to the rhythms of theory and world history makes one deaf. ${ }^{87}$

\section{Bibliography}

Ahmed, Asad Q. (2011), The Religious Elite of the Early Islamic Hijāz, Oxford: Unit for Prosopographical Research, Linacre College.

Beg, M.A.J. "Al-Khāșșa wa 'l-'Āmma”, The Encyclopaedia of Islam, $2^{\text {nd }}$ ed, available at http://dx.doi.org/10.1163/1573-3912_islam_SIM_4228, last accessed 31 July 2018.

Bériou, Nicole / Carraz, Damien (2015), "Conclusion. Les ordres militaires à la rencontre des élites”, in: P. Josserand, L. F. Oliveira, and D. Carraz, eds., Élites et ordres militaires au Moyen Âge, Madrid: Casa de Velázquez, 373-380.

Bourdieu, Pierre (1979), La distinction. Critique sociale du jugement, Paris: Les éditions de minuit. Translated by Richard Nice (1984), Distinction. A Social Critique of the Judgement of Taste, Cambridge, Mass.: Harvard University Press.

Bourdieu, Pierre (1986), “The Forms of Capital”, in: John G. Richardson, ed., Handbook of Theory and Research for the Sociology of Education, New York: Greenwood Press, 241-258.

Bulliet, Richard (1972), The Patricians of Nishapur, Cambridge, Mass.: Harvard University Press.

Cébeillac-Gervasoni, Mireille (2003), “Chronique des travaux et discussions”, in: Mireille Cébeillac-Gervasoni and Laurent Lamoine, eds., Les élites et leurs facettes. Les élites locales dans le monde hellénistique et romain, Rome: Presses Universitaires Blaise-Pascal, 703-732.

86 Dartmann et al. 2015, 37.

87 Mann 1986, viii. 
Christys, Ann (2018), “Educating the Christian Elite in Umayyad Córdoba”, in: Wolfram Drews, ed., Die Interaktion von Herrschern und Eliten in imperialen Ordnungen des Mittelalters, Berlin/Boston: De Gruyter, 114-124.

Couperus, Stefan / Smit, Christianne / Wolffram, Dirk J. (2007), “Introduction. Local Elites and Urban Politics-A Conceptual Framework", in: Stefan Couperus et al., eds., In Control of the City. Local Elites and the Dynamics of Urban Politics, 1800-1960, Leuven etc.: Peeters, ix-xix.

Daloz, Jean-Pascal (2010), The Sociology of Elite Distinction. From Theoretical to Comparative Perspectives, London: Palgrave Macmillan.

Dartmann, Christoph / Flüchter, Antje / Oesterleh, Jenny Rahel (2015), “Eliten in transkultureller Perspektive”, in: Wolfram Drews and Antje Flüchter, eds., Monarchische Herrschaftsformen der Vormoderne in transkultureller Perspektive, Berlin: De Gruyter, 33-171.

Dreyer, Boris / Mittag, Peter Franz, eds. (2011), Lokale Eliten und hellenistische Könige. Zwischen Kooperation und Konfrontation, Berlin: Verlag Antike.

Dumolyn, Jan (2013), “Later Medieval and Early Modern Urban Elites: Social Categories and Social Dynamics”, in: M. Asenjo-Gonzalez, ed., Urban Elites and Aristocratic Behaviour in the Spanish Kingdoms at the End of the Middle Ages, Turnhout: Brepols, 3-18.

Dumont, Louis (1980), Homo Hierarchicus: The Caste System and Its Implications, Chicago: University of Chicago Press.

Durand-Guédy, David (2010), Iranian Elites and Turkish Rulers. A History of Ișfahān in the Saljūq Period, London: Routledge.

El Hour, Rachid, ed. (2012), Cadíes y cadiazgo en el-Andalus y el Magreb medieval, Madrid: Consejo Superior de Investigaciones Científicas.

Endruweit, Günter (1979), “Elitenbegriffe in den Sozialwissenschaften”, Zeitschrift für Politik 26/1: $30-46$.

Fox, Yaniv (2014), Power and Religion in Merovingian Gaul. Columbanian Monasticism and the Formation of the Frankish Elites, Cambridge: Cambridge University Press.

Fuess, Albrecht / Hartung, Jan-Peter, eds. (2011), Court Cultures in the Muslim World: Seventh to Nineteenth Centuries, London: Routledge.

Genequand, Denis (2006), "Umayyad Castles: The Shift from Late Antique Military Architecture to Early Islamic Palatial Building”, in: Hugh Kennedy, ed., Muslim Military Architecture in Greater Syria, Leiden: Brill, 3-25.

Grey, Cam (2011), Constructing Communities in the Late Roman Countryside, Cambridge etc.: Cambridge University Press.

Gunn, Simon (2007), “Elites, Power and Governance”, in: Stefan Couperus et al., eds., In Control of the City. Local Elites and the Dynamics of Urban Politics, 1800-1960, Leuven etc.: Peeters, 191-202.

Haldon, John (2004), "Introduction”, in: John Haldon and Lawrence Conrad, eds., The Byzantine and Early Islamic Near East, VI: Elites Old and New, Princeton: Darwin Press, 1-11.

Haldon, John / Conrad, Lawrence, eds. (2004), The Byzantine and Early Islamic Near East, VI: Elites Old and New, Princeton: Darwin Press.

Haro Peralta, José / Verkinderen, Peter (2016), “'Find for me!’: Building a Context-Based Search Tool Using Python", in: Elias Muhanna, ed., The Digital Humanities and Islamic \& Middle East Studies, Berlin: De Gruyter, 199-232. 
Higley, John / Pakulski, Jan (2012), “Elite Theory versus Marxism: The Twentieth Century’s Verdict”, Historical Social Research 37/1: 320-332.

Hirschler, Konrad (2008), "The Formation of the Civilian Elite in the Syrian Province: The Case of Ayyubid and Early Mamluk Ḥamāh", Mamluk Studies Review 12/2: 95-132.

Höfert, Almut (2015), Kaisertum und Kalifat: Der imperiale Monotheismus im Früh- und Hochmittelalter, Frankfurt a. M./New York: Campus.

Horowitz , Irving L. (1981), “C. Wright Mills's Power Elite: A Twenty-Five-Year Retrospective”, The Antioch Review 39/3: 373-382.

Hourani, Albert (1981), “Ottoman Reform and the Politics of Notables”, in: Albert Hourani, The Emergence of the Modern Middle East, London: Macmillan.

Kennedy, Hugh (2011), "Great Estates and Elite Lifestyles in the Fertile Crescent from Byzantium and Sasanian Iran to Islam”, in: Albrecht Fuess and Jan-Peter Hartung, eds., Court Cultures in the Muslim World: Seventh to Nineteenth Centuries, London: Routledge, $54-79$.

Kennedy, Hugh (1981), “Central Government and Provincial Elites in the Early 'Abbasid Caliphate", Bulletin of the School of Oriental and African Studies 44/1: 26-38.

Kolegar, F. (1967), “The Elite and the Ruling Class: Pareto and Mosca Re-Examined”, The Review of Politics 29/3: 354-369.

Khoury, Philip S. (1983), Urban Notables and Arab Nationalism: The Politics of Damascus 1860-1920, Cambridge etc.: Cambridge University Press.

Lev, Yaacov (2007), "The Dismemberment of the Fatimid State and the Emergence of the New Ayyubid Elite in Egypt”, in: Urbain Vermeulen and Kristof D'Hulster, eds., Egypt and Syria in the Fatimid, Ayyubid and Mamluk Eras V, Leuven: Peeters, 129-152.

López, Matías (2013), “Elite Theory”, Sociopedia.isa, available at http://www.sagepub.net/ isa/resources/pdf/elitetheory.pdf, last accessed 31 July 2018.

Mann, Michael (1986), The Sources of Social Power, I: A History of Power from the Beginning to A.D. 1760 , Cambridge etc.: Cambridge University Press.

Marcus, George (1983), “Introduction”, in: George Marcus, ed., Elites: Ethnographic Issues, Albuquerque: University of New Mexico Press, 7-27.

Marlow, Louise (2016), Counsel for Kings: Wisdom and Politics in Tenth-Century Iran, 2 vols., Edinburgh: Edinburgh University Press.

Mills, C. Wright (2000), The Power Elite, new ed., New York: Oxford University Press.

Mitchell, Richard E. (1973), "The Aristocracy of the Roman Republic”, in: F. C. Jaher, ed., The Rich, the Well Born, and the Powerful. Elites and Upper Classes in History, Chicago: University of Illinois Press, 27-63.

Morris, Robert J. (1990), Class, Sect and Party, Manchester: Manchester University Press.

Mosca, Gaetano (1939), Elementi di scienza politica. Translated by Hannah de Kahn, The Ruling Class, edited and revised by Arthur Livingston, New York: McGraw-Hill.

Mottahedeh, Roy (1975), “Review of Richard Bulliet's The Patricians of Nishapur”, The Journal of the American Oriental Society 95: 491-495.

Nawas, John, "Client”, The Encyclopaedia of Islam, THREE, available at http://dx.doi.org/10.1163/1573-3912_ei3_COM_27126, last accessed 31 July 2018.

Nawas, John / Bernards, Monique (1998), "A Preliminary Report of the Netherlands Ulama Project (NUP): The Evolution of the Class of 'ulama') in Islam with Special Emphasis on the Non-Arab Converts (mawälĭ) from the First through Fourth Century A.H.”, in: U. 
Vermeulen and J. M. F. Van Reeth, eds., Law, Christianity and Modernism in Islamic Society, Leuven: Peeters, 97-107.

Nef, Annliese (2004), “Les élites savantes urbaines dans la Sicile islamique d'après les dictionnaires biographiques arabes”, in: Annliese Nef and Alessandra Molinari, eds., La Sicile à l'époque islamique, Rome: École Française de Rome, 451-470.

Pakulski, Jan (2012), "The Weberian Foundations of Modern Elite Theory and Democratic Elitism”, Historical Social Research 37/1: 38-56.

Pareto, Vilfredo (1968), The Rise and Fall of Elites: An Application of Theoretical Sociology, edited and translated by H. Zetterberg, Totowa: Bedminster Press.

Paul, Jürgen (1996), Herrscher, Gemeinwesen, Vermittler: Ostiran und Transoxanien in vormongolischer Zeit, Stuttgart: Steiner.

Paul, Jürgen (2016), Lokale und imperiale Herrschaft im Iran des 12. Jahrhunderts: Herrschaftspraxis und Konzepte, Wiesbaden: Reichert.

Payne, Richard (2015), “East Syrian Bishops, Elite Households and Iranian Law after the Muslim Conquest”, Iranian Studies 48/1: 5-32.

Preiser-Kapeller, Johannes (2012), “Networks of Border Zones-Multiplex Relations of Power, Religion and Economy in South-Eastern Europe, 1250-1453 CE”, in: Mingquan Zhou et al., eds., Proceedings of the 39th Annual Conference of Computer Applications and Quantitative Methods in Archaeology, "Revive the Past" (CAA) in Beijing, Amsterdam: Amsterdam University Press, 381-393.

Preiser-Kapeller, Johannes (2015), “Harbours and Maritime Mobility: Networks and Entanglements", in: Johannes Preiser-Kapeller and Falko Daim, eds., Harbours and Maritime Networks as Complex Adaptive Systems, Mainz: Verlag des Römisch-Germanischen Zentralmuseums, 119-139.

Preiser-Kapeller, Johannes (2018), “Central Peripheries. Empires and Elites Across Byzantine and Arab Frontiers in Comparison (700-900 CE)", in: Wolfram Drews, ed., Die Interaktion von Herrschern und Eliten in imperialen Ordnungen des Mittelalters, Berlin/Boston: De Gruyter, 91-113.

Robinson, Chase (2003), Islamic Historiography, Cambridge: Cambridge University Press. Romanov, Maxim (2013), Computational Reading of Arabic Biographical Collections, PhD Thesis, University of Michigan.

Settipani, Christian (2006), Continuité des élites à Byzance durant les siècles obscurs. Les princes caucasiens et l'empire du Vle au IXe siècle, Paris: de Boccard.

Shoshan, Boaz (1986), “The 'Politics of Notables' in Medieval Islam”, Asian and African Studies: Journal of the Israel Oriental Society 20: 179-215.

Tacoma, Laurens E. (2006), Fragile Hierarchies: The Urban Elites of Third-Century Roman Egypt, Leiden/Boston: Brill.

Toru, M. / Philips, J. E., eds. (2000), Slave Elites in the Middle East and Africa: A Comparative Study, Cardiff: Kegan Paul International.

Van Renterghem, Vanessa (2004), Les élites bagdadiennes au temps des Seldjoukides, PhD thesis, Université Paris I.

Van Renterghem, Vanessa (2015), Les élites bagdadiennes au temps des Seldjoukides. Étude d'histoire sociale, 2 vols., Beirut/ Damascus: Presses d'IFPO.

Van Steenbergen, Jo (2005), "Mamluk Elite on the Eve of al-Nāṣir Muḥammad's Death (1341): A Look Behind the Scenes of Mamluk Politics", Mamluk Studies Review 9/2: 173-199. 
Verboven, Koenraad / Carlier, Myriam / Dumolyn, Jan (2007), "A Short Manual to the Art of Prosopography”, in: Koenraad Verboven, Myriam Carlier, and Jan Dumolyn, eds., Prosopography Approaches and Applications. A Handbook, Oxford: P\&G, 35-70.

Weber, Max (1922), Wirtschaft und Gesellschaft. Dritter Teil: Typen der Herrschaft, Tübingen: Mohr.

Wickham, Chris (2004), “Conclusion”, in: John Haldon and Lawrence Conrad, eds., The Byzantine and Early Islamic Near East, VI: Elites Old and New, Princeton: Darwin Press, 285-297.

Wickham, Chris (2005), Framing the Early Middle Ages, Oxford: Oxford University Press. Zetterberg, Hans (1968), “Introduction”, in: Vilfredo Pareto, The Rise and Fall of Elites: An Application of Theoretical Sociology, edited and translated by H. Zetterberg, Totowa: Bedminster Press, 1-22. 